\title{
Adaptation and validation of the Advanced Practice Nursing Competency Assessment Instrument
}

\author{
Adaptação e validação do Inventario para Evaluación de Competencias en Enfermeras de Práctica Avanzada \\ Adaptación y validación del Inventario para Evaluación de Competencias em Enfermeras de Práctica Avanzada
}

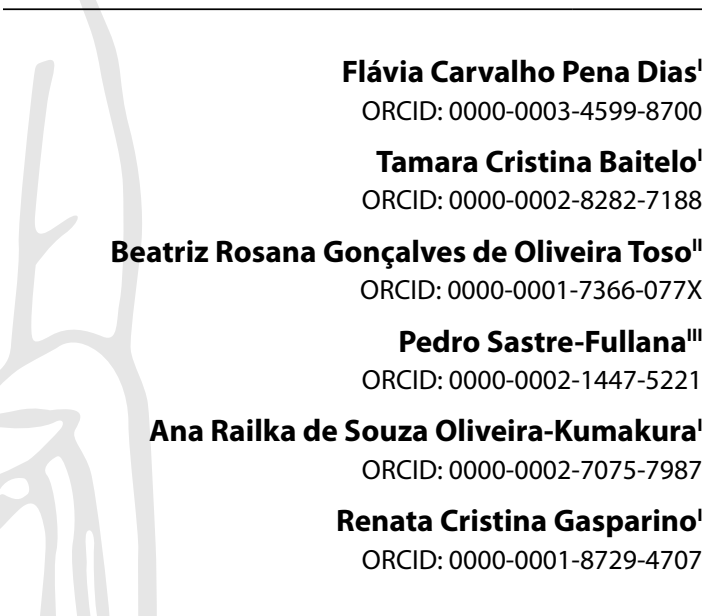

'Universidade Estadual de Campinas. Campinas, São Paulo, Brazil. "Universidade Estadual do Oeste do Paraná. Cascavel, Paraná, Brazil. "'Hospital Universitario Son Espases. Palma de Mallorca, Illes Balears, Espanha.

How to cite this article: Dias FCP, Baitelo TC, Toso BRGO, Sastre-Fullana P Oliveira-Kumakura ARS, Gasparino RC. Adaptation and validation of the Advanced Practice Nursing Competency Assessment Instrument. Rev Bras Enferm. 2022;75(5):e20210582. https://doi.org/10.1590/0034-7167-2021-0582

Corresponding author: Flávia Carvalho Pena Dias E-mail: flapena@gmail.com

EDITOR IN CHIEF: Antonio José de Almeida Filho ASSOCIATE EDITOR: Maria Itayra Padilha

\begin{abstract}
Objective: To adapt and validate the content of the Advanced Practice Nursing Competency Assessment Instrument (APNCAI) to Brazilian culture. Methods: This is a methodological study that followed the stages of translation, synthesis, back translation, evaluation by a committee of five specialists, pre-test with 31 nurses, and evaluation by the author of the original instrument. The Content Validity Index (minimum 0.90) and the modified Kappa (minimum 0.74) were calculated to evaluate the content. Result: In the first round of content evaluation, 18 items had to be altered because they did not reach the minimum values established. Three items have not reached a consensus in the second round and had to be sent to the author of the original version. In the pre-test, 13 items were returned to the specialists because they suffered content changes. Conclusion: The Advanced Practice Nursing Competency Assessment Instrument (APNCAI) - Brazilian version was cross-culturally adapted, and its content was validated. Descriptors: Translation; Validation Studies; Role of the Nursing Professional; Clinical Competence; Advanced Practice Nursing.
\end{abstract}

\section{RESUMO}

Objetivo: Adaptar e validar o conteúdo do Inventario para la Evaluación de Competencias en Enfermeras de Práctica Avanzada para a cultura brasileira. Métodos: Estudo metodológico que seguiu os estágios de tradução, síntese, retrotradução, avaliação por um comitê de cinco especialistas, pré-teste com 31 enfermeiros e avaliação pelo autor do instrumento original. Para avaliar o conteúdo, foram calculados o Índice de Validade de Conteúdo (mínimo 0,90) e o Kappa modificado (mínimo 0,74). Resultado: Na primeira rodada de avaliação do conteúdo, 18 itens foram alterados, pois não alcançaram os valores mínimos estabelecidos. Na segunda rodada, três itens não obtiveram consenso e foram encaminhados para o autor da versão original. No pré-teste, 13 itens retornaram aos especialistas, pois sofreram alteração de conteúdo. Conclusão: O Instrumento para Avaliação de Competências do Enfermeiro de Prática Avançada - versão brasileira foi adaptado transculturalmente e teve seu conteúdo validado. Descritores: Tradução; Estudos de Validação; Papel do Profissional de Enfermagem; Competência Clínica; Prática Avançada de Enfermagem.

\section{RESUMEN}

Objetivo: Adaptar y validar el contenido del Inventario para la Evaluación de Competencias en Enfermeras de Práctica Avanzada para la cultura brasileña. Métodos: Estudio metodológico que siguió las etapas de traducción, síntesis, retrotraducción, evaluación por un comité de cinco especialistas, pretest con 31 enfermeros y evaluación por el autor del instrumento original. Para evaluar el contenido, fueron calculados el Índice de Validez de Contenido (mínimo 0,90) y el Kappa modificado (mínimo 0,74). Resultado: En la primera fase de evaluación del contenido, 18 ítems fueron alterados, pues no alcanzaron los valores mínimos establecidos. En la segunda fase, tres ítems no obtuvieron consenso y fueron encaminados para el autor de la versión original. En el pretest, 13 ítems volvieron a los especialistas, pues sufrieron alteración de contenido. Conclusión: El Instrumento para Evaluación de Competencias del Enfermero de Práctica Avanzada - versión brasileña fue adaptado transculturalmente y tuvo su contenido validado. Descriptores: Traducción; Estudios de Validación; Rol de la Enfermera; Competencia Clínica; Enfermería de Práctica Avanzada. 


\section{INTRODUCTION}

Currently, there is a growing interest in different countries to adhere to practices that can innovate and improve the access of patients/users to health systems to support the needs of the population, mainly due to the rise of chronic diseases. However, the shortage of qualified workers to offer quality health care is a problem that needs to be faced ${ }^{(1)}$; for this, Advanced Practice Nursing (APN) emerges as an up-and-coming option.

The APN first emerged in the United States in 1960 and consisted of a complex process encompassing research, education, care practice, and management. The nurse developing this practice must make complex decisions concerning the users' assistance, considering the context they are accredited to act ${ }^{(2)}$. Therefore, it is necessary that this professional has specialized knowledge acquired through graduate courses, integrates a multidisciplinary team, and practices in care management for patients/users with acute and chronic conditions $s^{(3)}$. Hence, they must have the ability to perform assessments, propose diagnoses, prescriptions, implement projects and care proposals, and be a reference in the contact between patients/users and health services ${ }^{(2)}$.

The successful implementation of this practice is associated with expressive results, such as more time and quality of assistance offered to patients, improved access to health, higher user satisfaction rates, and higher levels of satisfaction and retention of qualified professionals ${ }^{(4-6)}$. In Brazil, this process is still incipient ${ }^{(7)}$ since it requires the transformation of practice scenarios and, consequently, changes in legislation and professional regulation $^{(3)}$. Still, it seems to be quite promising.

In 2015 and 2016, the Federal Council of Nursing, the Brazilian Association of Nursing, and other health and education entities increased discussions on the implementation of APN in the Brazilian territory and established three acting axes: strengthening of research lines on the topic; implementation of core areas of advanced practice learning for resident nurses of multi-professional programs; drug prescription guided by regulations ${ }^{(8-9)}$.

Brazil has several undergraduate and graduate Nursing courses and pilot projects under development ${ }^{(10-11)}$. In addition, the Law of Professional Practice and the National Policy of Primary Care already ensure autonomy for nurses to perform several activities in their professional practice ${ }^{(8,10)}$, the basis for APN implementation.

So, it is understood that advanced practice is a new model of nursing care based on specialized, problem-solving, effective, and autonomous care. The professionals' roles and competencies who exercise this practice are being developed through sociopolitical transformations and leadership actions, use of information technology, implementation of evidence-based practice, and concern with ethical and safe care to meet the needs of health systems and citizens ${ }^{(2,8)}$.

With the intention of mapping and helping managers execute actions that collaborate with the development of the necessary competencies for the performance of advanced practice nurses in health services, different instruments have been built. Among them, we point out the Advanced Practice Nursing Competency Assessment Instrument - APNCAI (7,11-14).

The APNCAI was developed in Spain in 2017 and aims to assess nurses' competencies for advanced practice in primary care and hospital settings. The validation of this instrument was successful since construct validity was assessed by exploratory factor analysis, followed by confirmatory analysis. The instrument's final version resulted in 44 items, distributed in eight dimensions: Research and Evidence-Based Practice; Clinical and Professional Leadership; Professional Autonomy; Interprofessional Relations and Mentoring; Quality Management; Care Management; Professional Teaching and Education; and Health Promotion ${ }^{(14)}$.

For the eight-dimensional model fit, first, the Kaiser MeyerOlkin (KMO) (0.96) and Bartlett's test of sphericity $(p<0.0001)$ were calculated. Then, satisfactory values were obtained for the Root Mean Square Error of Approximation (RMSEA) (0.05), for the Comparative Fit Index (CFI) (0.99), and finally for the Standardised Root Mean Square Residual (SRMR) (0.05). The factorial loadings ranged from 0.50 to 0.87 . In the reliability analysis, Cronbach's alpha values among the different dimensions were higher than 0.80 and ranged between 0.81 and $0.92^{(14)}$.

Because the validation process of the instrument was conducted with methodological rigor and demonstrated that it could be applied in services at different levels of health care, we believe that the availability of the APNCAI for the Brazilian culture may favor the development of research whose results may support the implementation of strategies that will contribute to the formalization of the APN in Brazil. Through this practice, it is expected that the population will have more access to health services, and, consequently, better indicators related to patient care will be achieved.

\section{OBJECTIVE}

Adapt and validate the content of the Advanced Practice Nursing Competency Assessment Instrument for the Brazilian culture.

\section{METHODS}

\section{Ethical aspects}

The author ${ }^{(14)}$ of the original instrument granted his consent for the process of cross-cultural adaptation and validation of the APNCAI for the Brazilian context. The Research Ethics Committee of the State University of Campinas approved the study.

\section{Design, period, and place of study}

That is a methodological study, conducted online between August 2019 and June 2020, through six stages: translation; synthesis; back-translation; evaluation of the content by a committee of specialists; pre-test; and evaluation of the final version by the author of the original instrument ${ }^{(15)}$. For the description of the research, the criteria of the checklist Consensus-Based Standards for the selection of health Measurement Instruments (COSMIN) ${ }^{(16)}$.

\section{Population or sample: criteria of inclusion and exclusion}

The members of the specialist committee were selected from the Lattes Platform, and the following filters were used as inclusion criteria: "Advanced Practice Nursing" or "Validation Studies" and updated curricula in the last year. 
As a result, the search yielded 449 curricula. Researchers recommend a sample size between five and ten participants ${ }^{(17)}$ for studies that assess content validity; therefore, we chose a sample size four times the maximum recommended to compensate for possible losses and rejections in the present study. A probabilistic systematic sampling method was used to select the 40 resumes, and a resume was selected after a range of ten sampling units. Thus, an invitation was sent by e-mail to the specialists, explaining the objectives of the study.

For the pre-test, the recommended sample consists of 30 and 40 participants ${ }^{(18)}$. The nurses with at least a specialist title and one year of experience were selected by convenience and received an e-mail invitation to participate in the research.

\section{Study protocol}

The cross-cultural adaptation was carried out in six stages ${ }^{(15)}$. In the first one, named Translation, the original version of the instrument (Spanish) was translated by independent translators (T1 and T2), fluent in Spanish and having Brazilian Portuguese as their mother tongue. Only one of the translators was informed about the conceptual structure and objectives of the study ${ }^{(15)}$.

In the second stage, it was performed the Synthesis of the translations, in which the translated versions of the instrument ( $\mathrm{T} 1$ and $\mathrm{T} 2$ ) were synthesized by a third translator, who was a native speaker of Portuguese and fluent in Spanish, which resulted in the synthesis version(T12)(15).

In the third stage (back-translation), T12 was back-translated by two other independent Spanish translators, fluent in Portuguese. Thus, BT1 and BT2 were produced. It is noteworthy that these translators were not informed about the concepts and purposes of the study ${ }^{(15)}$.

The Specialists Committee (fourth stage) was composed of five specialists with clinical experience. Specialists in the conceptual structure of the instrument or experienced in the process of adaptation and validation of measurement instruments ${ }^{(17)}$. They assessed semantic equivalencies (meaning of words), idiomatic (colloquial expressions), cultural (whether the terms used in the original version are consistent with the experiences of the target population), and conceptual (whether the items assess the construct that is being measured) between the original and synthesis versions (T12)(15).

The first stage of evaluating these equivalences is quantitative due to the Content Validity Index (CVI) and the modified Kappa coefficient calculation. For the items that did not reach the minimum score established, we analyzed the specialists' suggestions; and the changes incorporated into the instrument in that other stage were called "qualitative." After this, a new round of evaluation was initiated until reaching a consensus ${ }^{(17,19)}$.

In the fifth stage, named Pre-test, the pre-final version, in the target language, and content validated by the group of specialists, was tested by 31 nurses to assess clarity, the ease of understanding the items, and the practical aspects of applying the instrument. The participants were asked to record the time to complete the instrument and evaluate how easy it was to understand the items and the response scale using a four-point Likert-type scale, where 1 point represented "strongly disagree" and 4 points, "strongly agree." Scores of 1 or 2 were asked to include suggestions for changes in the lines at the end of the instrument. When suggestions altered the content, the item was forwarded to be reviewed by the specialist committee ${ }^{(17)}$.

In the last stage, the Evaluation in the final version, the Brazilian version of the instrument, was sent to the original instrument author for appreciation and validation of the process ${ }^{(15)}$.

\section{Analysis of results and statistics}

The data obtained were tabulated in Microsoft Excel for Windows ${ }^{\circ}$ spreadsheets, in which the position measures of quantitative variables and frequency measures of qualitative variables were calculated. In content validation, the CVI and the modified Kappa coefficient were used for each of the equivalence, clarity, and representativeness, with minimum values of 0.90 and 0.74 considered acceptable, respectively ${ }^{(17,20)}$. The items were evaluated using a Likert-type scale ranging from 1 to 4 points; and, for the specialists who assigned scores of 1 (absolutely not equivalent, not clear and not relevant) or 2 (equivalent, clear and relevant, but in need of significant changes) to some item, suggestions for improvement were requested ${ }^{(17)}$. In all analyses, it was used the Statistical Analysis Software (SAS), version 9.4.

\section{RESULTS}

Certified companies carried out the first three stages of the cross-cultural adaptation process without difficulties. In the first round of the fourth stage, content validation, the CVI was 0.6 ; and the modified Kappa was 0.42. The title, after the incorporation of the specialists' suggestions, was changed from "Inventario para la Evaluación de Competencias en Enfermeras de Práctica Avanzada - IECEPA - versão brasileira" to "Instrumento para Avaliação de Competências do Enfermeiro de Prática Avançada - IECEPA - versão brasileira" (Advanced Practice Nursing Competency Assessment Instrument - APNCAI - Brazilian version).

Regarding the introduction, the CVI was 0.8 , and the modified Kappa was 0.76 for equivalencies and clarity. After modifications, the text was changed, resulting in "Indicate, by marking an $\mathrm{X}$, the frequency with which you perform the following activities in your professional practice. Each group of activities is associated with a specific dimension of the nursing profession; and, in your self-assessment, you should take into consideration only the activities performed by you."

Concerning the dimensions, only the fourth one (Interprofessional relationship and guidance) obtained a CVI of 0.8 and a modified Kappa of 0.76 , in idiomatic equivalence and clarity. After observations by the specialists, it was changed to "Interprofessional relationship and mentoring."

As for CVI and modified Kappa, the items that did not reach minimum values of 0.90 and 0.74 , respectively, were represented in Table 1.

Six items were absent in Table 1 (2.2, 2.3, 3.8, 4.1, 4.2, and 7.4) because they reached a CVI of 1.00 and modified Kappa of 0.76 . They received suggestions for grammar changes and had to be reformulated. However, since the content did not change, they were not forwarded for evaluation by specialists. 
Besides these, seven other items $(1.4,1.8,3.2,4.3,5.2,6.5$, and 6.6) also reached $100 \%$ agreement. Specialists made suggestions to improve it. The items had to be reformulated after the researchers' evaluation; however, they were returned for the specialists' evaluation because it was considered that the content suffered an impact.

Thus, 18 items $(1.1,1.4,1.5,1.6,1.7,1.8,2.4,3.1,3.2,3.5,4.3,4.6$, $5.2,6.5,6.6,8.1,8.2$, and 8.3 ) were sent to the second round of evaluation by the specialists. On this occasion, the title, the introduction, and the fourth dimension reached $100 \%$ agreement. Regarding the items, nine $(1.4,1.5,1.6,1.8,3.2,3.5,4.3,6.5$, and 6.6$)$ obtained $100 \%$ agreement on the changes made; in four $(1.1,1.7,2.4$, and 3.1$)$, although no there was consensus, minor suggestions were made and accepted by the researchers. For two items ( 4.6 and 5.2) that did not reach an agreement, two specialists requested that they should be rewritten as they were previously in $\mathrm{T} 12$, but these requests were not accepted. In addition, three more items $(8.1,8.2$, and 8.3$)$ did not meet the established values for CVI and modified Kappa.

The lack of consensus on items 8.1, 8.2, and 8.3 occurred because some specialists understood that the APN should include all users, i.e., newborns to the elderly; however, others claimed that this practice applies only to adolescents and adults. To resolve this doubt, the researchers consulted the author of the original instrument, whose advice was that the items should cover all users.

Therefore, at the end of this step, these three items were worded as follows: 8.1 - I participate in the development and implementation of health promotion programs; 8.2 - I offer secondary and tertiary prevention to users/patients with multiple health problems or chronic diseases; and 8.3 - I promote users/ patients'self-care within the whole family and/or support systems and facilitate their participation in health care when appropriate. The summary version and the changes made in the first and second rounds for these items are shown in Chart 1.

At the end of the content validation, the pre-test was initiated with 31 nurses, being 10 (32.2\%) PhDs, 3 (9.7\%) doctoral students, 1 (3.2\%) master's, 6 (19.4\%) master's students, and 11 (35.5\%) specialists $(n=11 ; 35.5 \%)$. In the practicality evaluation, the average time to fill out the questionnaire was 16 minutes (SD \pm 8 , Min: 8.0, Max: 40). The great majority ( $n=30 ; 96.7 \%$ ) of the professionals agreed with the ease of understanding of the items and the answer options; however, 20 professionals suggested changes in 30 items, aiming to improve the Brazilian understanding version.

According to the researchers' assessment 13 items had their content changed $(1.1,1.2,2.1,2.3,2.4,3.1,3.3,3.6,4.2,5.1,6.3$, 6.5 , and 7.4). They agreed with the changes in six items $(1.1,1.2$, $2.1,3.1,3.3$, and 3.6$)$ suggested by the nurses. In items $2.3,2.4$, and 5.1 , the specialists chose to include definitions to the item to improve clarity: for example, item 2.3 changed from"I provide specialist guidance based on clinical data." to"I provide consulting services (specialized guidance) based on clinical data."

Table 1 - Content Validity Index and modified Kappa of items of the instrument that did not reach the minimum scores established referring to semantic, idiomatic, cultural, and conceptual equivalence, clarity, and relevance, Campinas, São Paulo, Brazil, 2021

\begin{tabular}{|c|c|c|c|c|c|c|c|c|c|c|c|c|}
\hline \multirow{3}{*}{ Item } & \multicolumn{8}{|c|}{ Equivalencies } & \multicolumn{2}{|c|}{ Clarity } & \multicolumn{2}{|c|}{ Relevance } \\
\hline & \multicolumn{2}{|c|}{ Semantic } & \multicolumn{2}{|c|}{ Idiomatic } & \multicolumn{2}{|c|}{ Conceptual } & \multicolumn{2}{|c|}{ Cultural } & & & & \\
\hline & CVI & Kappa & CVI & & CVI & Kappa & CVI & & CVI & Kappa & CVI & Kappa \\
\hline 1.1 & 0.60 & 0.42 & 0.80 & 0.76 & 0.80 & 0.76 & 0.80 & 0.76 & 0.80 & 0.76 & 1.00 & 1.00 \\
\hline 1.5 & 0.80 & 0.76 & 0.80 & 0.76 & 0.80 & 0.76 & 0.80 & 0.76 & 0.80 & 0.76 & 1.00 & 1.00 \\
\hline 1.6 & 0.80 & 0.76 & 1.0 & 1.00 & 1.00 & 1.00 & 1.00 & 1.00 & 1.00 & 1.00 & 1.00 & 1.00 \\
\hline 1.7 & 0.80 & 0.76 & 0.80 & 0.76 & 0.80 & 0.76 & 0.80 & 0.76 & 0.80 & 0.76 & 0.80 & 0.76 \\
\hline 2.4 & 0.80 & 0.76 & 0.80 & 0.76 & 0.80 & 0.76 & 0.80 & 0.76 & 0.60 & 0.42 & 0.80 & 0.76 \\
\hline 3.1 & 0.60 & 0.42 & 0.60 & 0.42 & 0.80 & 0.76 & 0.80 & 0.76 & 0.80 & 0.76 & 0.80 & 0.76 \\
\hline 3.5 & 0.80 & 0.76 & 0.80 & 0.76 & 0.80 & 0.76 & 0.80 & 0.76 & 0.80 & 0.76 & 0.80 & 0.76 \\
\hline 4.6 & 0.80 & 0.76 & 0.80 & 0.76 & 0.80 & 0.76 & 0.80 & 0.76 & 0.80 & 0.76 & 0.80 & 0.76 \\
\hline 8.1 & 1.00 & 1.00 & 1.00 & 0.76 & 0.80 & 1.00 & 1.00 & 1.00 & 1.00 & 1.00 & 1.00 & 1.00 \\
\hline 8.2 & 1.00 & 1.00 & 1.00 & 0.76 & 0.80 & 1.00 & 1.00 & 1.00 & 1.00 & 1.00 & 1.00 & 1.00 \\
\hline 8.3 & 1.00 & 1.00 & 1.00 & 0.76 & 0.80 & 1.00 & 1.00 & 1.00 & 1.00 & 1.00 & 1.00 & 1.00 \\
\hline
\end{tabular}

Chart 1 - Synthesis version and version resulting from the first and second round of evaluation by the experts committee, Campinas, São Paulo, Brazil, 2020

\begin{tabular}{|c|l|l|l|}
\hline Item & Synthesis version - T12 & Version resulting from the first evaluation round & Pre-test version \\
\hline 1.1 & $\begin{array}{l}\text { I work well as a primary researcher or } \\
\text { collaborator with other health team } \\
\text { professionals or with the community setting; } \\
\text { I identify, conduct, and support research that } \\
\text { promotes or benefits health care. }\end{array}$ & $\begin{array}{l}\text { I work either as the principal investigator or in } \\
\text { collaboration with other health team professionals } \\
\text { or with the community setting; I identify, lead, and } \\
\text { support research that promotes or benefits health } \\
\text { attention. }\end{array}$ & $\begin{array}{l}\text { I work as a principal investigator } \\
\text { or collaborator with other health } \\
\text { team professionals or with } \\
\text { the community setting; I shall } \\
\text { identify, conduct, and support } \\
\text { research that promotes or } \\
\text { benefits health attention. }\end{array}$ \\
\hline 1.4 & $\begin{array}{l}\text { I lead the development of evidence- } \\
\text { based plans to meet individuals, families, } \\
\text { communities, and populations' needs. }\end{array}$ & $\begin{array}{l}\text { I lead the development of evidence-based plans } \\
\text { to meet individuals, families, communities, and } \\
\text { populations' needs. }\end{array}$ & $\begin{array}{l}\text { I apply effective strategies for changing } \\
\text { professional conduct and teamwork to } \\
\text { promote evidence-based practices and } \\
\text { innovations in health care practice. }\end{array}$ \\
\hline \multicolumn{2}{|l}{$\begin{array}{l}\text { I use effective strategies to change professional } \\
\text { conduct and teamwork to promote evidence-based } \\
\text { practices and innovations in health attention practice. }\end{array}$} & \\
\hline
\end{tabular}




\begin{tabular}{|c|c|c|c|}
\hline Item & Synthesis version - T12 & Version resulting from the first evaluation round & Pre-test version \\
\hline 1.6 & $\begin{array}{l}\text { I implement evidence-based algorithms, } \\
\text { clinical guides, protocols, and interventions for } \\
\text { the population. }\end{array}$ & $\begin{array}{l}\text { I implement evidence-based algorithms, clinical } \\
\text { guides, protocols, and clinical management flowcharts } \\
\text { for the population. }\end{array}$ & \\
\hline 1.7 & $\begin{array}{l}\text { I develop and implement mechanisms for } \\
\text { periodic oversight and evaluation of policies } \\
\text { that might influence health care services and } \\
\text { interpret them into projects, structures, and } \\
\text { programs. }\end{array}$ & $\begin{array}{l}\text { I develop and implement periodic oversight and } \\
\text { evaluation mechanisms of policies influencing } \\
\text { health attention services and interpret them } \\
\text { into planning, structures, and health programs. }\end{array}$ & $\begin{array}{l}\text { I develop and implement } \\
\text { periodic oversight and } \\
\text { evaluation mechanisms of } \\
\text { policies influencing health } \\
\text { attention services and interpret } \\
\text { them into plans, structures, and } \\
\text { health programs. }\end{array}$ \\
\hline 1.8 & $\begin{array}{l}\text { I lead the promotion of interdisciplinary } \\
\text { collaborations to implement outcome- } \\
\text { oriented patient care programs that can } \\
\text { meet the clinical needs of patients, families, } \\
\text { populations, and communities. }\end{array}$ & $\begin{array}{l}\text { I lead the promotion of interdisciplinary } \\
\text { collaborations to implement outcome-oriented } \\
\text { patient attention programs that can meet the } \\
\text { clinical needs of patients, families, populations, and } \\
\text { communities. }\end{array}$ & \\
\hline 2.4 & $\begin{array}{l}\text { I issue recommendations based on the } \\
\text { consulting process. }\end{array}$ & $\begin{array}{l}\text { I make recommendations based on directions } \\
\text { obtained by a specialist nurse. }\end{array}$ & $\begin{array}{l}\text { I make recommendations based } \\
\text { on a consulting process. }\end{array}$ \\
\hline 3.1 & $\begin{array}{l}\text { I prescribe, order and/or implement } \\
\text { pharmacological and non-pharmacological } \\
\text { interventions, treatments, and procedures } \\
\text { as defined in health care plans within the } \\
\text { appropriate legislative context. }\end{array}$ & $\begin{array}{l}\text { I prescribe, delegate and/or implement } \\
\text { pharmacological and non-pharmacological } \\
\text { interventions, treatments, and procedures as defined } \\
\text { in health attention plans within the appropriate } \\
\text { legislative context. }\end{array}$ & $\begin{array}{l}\text { I prescribe, direct and/or } \\
\text { implement pharmacological } \\
\text { and non-pharmacological } \\
\text { interventions, treatments, and } \\
\text { procedures as defined in health } \\
\text { attention plans within the } \\
\text { appropriate legislative context. }\end{array}$ \\
\hline 3.2 & $\begin{array}{l}\text { I diagnose complex and unstable health } \\
\text { problems through collaboration and } \\
\text { consultation with the multidisciplinary health } \\
\text { team, as indicated by context, specialty, and } \\
\text { personal knowledge and experience. }\end{array}$ & $\begin{array}{l}\text { I diagnose complex and unstable health problems } \\
\text { through collaboration and consultation with the } \\
\text { health attention multidisciplinary team, as indicated } \\
\text { by context, specialty, and personal knowledge and } \\
\text { experiences. }\end{array}$ & \\
\hline 3.5 & $\begin{array}{l}\text { I select, prescribe, and supervise therapeutic, } \\
\text { pharmacological, and non-pharmacological } \\
\text { interventions, diagnostic measures, } \\
\text { equipment, procedures, and treatments to } \\
\text { meet the needs of patients, families, and } \\
\text { groups, following professional training, } \\
\text { institutional privileges, local and state laws, } \\
\text { and professional regulations. }\end{array}$ & $\begin{array}{l}\text { I select, prescribe, and supervise therapeutic, } \\
\text { pharmacological, and non-pharmacological } \\
\text { interventions, diagnostic measures, equipment, } \\
\text { procedures, and treatments to meet the needs of } \\
\text { patients, families, and groups, following professional } \\
\text { training, institutional regulations, local and state laws, } \\
\text { and professional } \\
\text { regulations. } \\
\text {. }\end{array}$ & \\
\hline 4.3 & $\begin{array}{l}\text { I collaborate with health team members } \\
\text { to provide inter-professional health care } \\
\text { centered on patient, family, and/or community } \\
\text { at the individual, organizational, and systemic } \\
\text { levels. }\end{array}$ & $\begin{array}{l}\text { I collaborate with health attention team members to } \\
\text { provide inter-professional health assistance centered } \\
\text { on patient, family, and/or community at the individual, } \\
\text { organizational, and systemic levels. }\end{array}$ & \\
\hline 4.6 & $\begin{array}{l}\text { I mentor the health team, students, and other } \\
\text { professionals to acquire new knowledge and } \\
\text { skills to help them in their professional practice. }\end{array}$ & $\begin{array}{l}\text { I tutor the health care staff, students, and other } \\
\text { professionals in acquiring new knowledge and skills to } \\
\text { help them practice their profession. }\end{array}$ & \\
\hline 5.2 & $\begin{array}{l}\text { I propose innovations to effect changes in } \\
\text { clinical practice and improvements in health } \\
\text { care outcomes. }\end{array}$ & $\begin{array}{l}\text { I propose innovations to make changes in clinical } \\
\text { practice and improvements in health attention } \\
\text { outcomes. }\end{array}$ & \\
\hline 6.5 & $\begin{array}{l}\text { I contribute to developing the overall health } \\
\text { care system and adopt nursing models used in } \\
\text { the system to achieve the best results. }\end{array}$ & $\begin{array}{l}\text { I contribute to the development of the global health } \\
\text { care system and adopt nursing models used in the } \\
\text { system to achieve the best results. }\end{array}$ & \\
\hline 6.6 & $\begin{array}{l}\text { I promote the ability of patients, families and/ } \\
\text { or communities to participate in decisions } \\
\text { related to the process of their health needs, } \\
\text { according to an assessment of patients, } \\
\text { families and/or communities' preferences with } \\
\text { whom I work with and available resources. }\end{array}$ & $\begin{array}{l}\text { I promote the patients' capacity, families and/or } \\
\text { communities to participate in decisions related to } \\
\text { the attention process to their health needs, according } \\
\text { to the evaluation of their preferences and available } \\
\text { resources. }\end{array}$ & \\
\hline 8.1 & $\begin{array}{l}\text { I participate in the development and } \\
\text { implementation of health promotion } \\
\text { programs for adolescents and adults. }\end{array}$ & $\begin{array}{l}\text { I participate in the development and implementation } \\
\text { of health promotion programs. }\end{array}$ & There was no consensus. \\
\hline
\end{tabular}


Table 1 (concluded)

\begin{tabular}{|c|l|l|l|}
\hline Item & Synthesis version - T12 & Version resulting from the first evaluation round & Pre-test version \\
\hline 8.2 & $\begin{array}{l}\text { I offer secondary and tertiary prevention for } \\
\text { adolescents and adults with multiple health } \\
\text { problems or chronic diseases. }\end{array}$ & $\begin{array}{l}\text { I offer secondary and tertiary prevention to users/ } \\
\text { patients with multiple or chronic health problems. }\end{array}$ & There was no consensus. \\
\hline 8.3 & $\begin{array}{l}\text { I promote self-care in adolescents and adults } \\
\text { within the whole family and/or support } \\
\text { systems and facilitate their participation in } \\
\text { health care when appropriate. }\end{array}$ & $\begin{array}{l}\text { I promote users/patients' self-care within the whole } \\
\text { family and/or support systems and facilitate their } \\
\text { participation in health care when appropriate. }\end{array}$ & There was no consensus. \\
\hline
\end{tabular}

For the other items, the changes were minor, such as: "I encourage the health care team to share with me..." to"I encourage the members of the health care team to share with me..." and "I contribute to the development of global health" to "I contribute to the development of the global health system," for example.

Thus, the final version of the Advanced Practice Nursing Competency Assessment Instrument (APNCAI) - Brazilian version was sent to the author of the original instrument, who approved the conducted process.

\section{DISCUSSION}

The process of cross-cultural adaptation of a scale is rigorous and complex; for this reason, it demands the fulfillment of a series of requirements, which aims to achieve equivalence between the original version and the adapted version of the instrument ${ }^{(15)}$. Those requirements met the cross-cultural adaptation of the APNCAI for the Brazilian culture, which was systematically carried out, according to international literature's recommendations, similar to other studies ${ }^{(21-22)}$.

In the synthesis stages of translations and back-translation, there was a divergence of opinion in literature because, although most researchers perform these steps ${ }^{(21)}$, there is already evidence that the specialists' committee can perform the synthesis. The backs do not need to be produced since they constitute the superposition of one translation over another and may distort the original version of the instrument ${ }^{(23)}$. However, in this study, we chose to perform these steps because we consider them included in the methodological reference adopted ${ }^{(15)}$.

In the composition of the specialists' committee, this research met the recommendations of the literature. That was evident in other studies observing the number and characteristics of participants ${ }^{(21-22)}$; however, among the studies cited, only one ${ }^{(22)}$ also assessed, besides the equivalence, the clarity, and relevance of the items. As for the analysis of the agreement, two studies, besides the CVI, used the modified Kappa ${ }^{(2122)}$.

It is noteworthy that although the researchers invited four times more specialists than the maximum number recommended for the composition of a committee, only five accepted to participate, which is why the $C V I$ raised from the 0.80 recommended in the literature ${ }^{(17)}$ to 0.90 , to ensure content validation better.

In the fourth stage of the research, it is worth noting that the assessment of the clarity, the representativeness, the modified Kappa, and the minimum CVI of 0.90 constitute a differential of the present study and demonstrate the methodological rigor used during the process. Another positive point to be highlighted in this stage was the online procedure because authors affirm that face-to-face meetings may suffer the domination of some people in the communication process, contributing to other people not expressing themselves freely. Besides that, in this type of meeting, there are geographical limitations ${ }^{(19)}$.

When analyzing the changes proposed by specialists in the Research and Evidence-Based Practice dimension, although most items scored below the established in all evaluations, it was possible to observe that most of them were related to the concepts of "attention" and "health care." One change made in more than one item of this dimension was the replacement of the expression "health care" by "health attention" because it was understood that "health attention" encompasses "health care" at any level of care $^{(24)}$.

Although scholars state that only $18 \%$ of primary care are based on research results ${ }^{(25)}$, the APN considers essential the implementation of evidence-based practice; therefore, in this first dimension of APNCAI, the items assess nurses' involvement in research and implementation of evidence, considering that this is the way to achieve safe and more qualified care ${ }^{(25)}$.

In the Clinical and Professional Leadership dimension, the items address the importance of the advanced practice nurse contributing to the implementation of innovations and guiding the evolution of the work. For this, the word "consulting" is used in the original version of the instrument, but researchers point out specific difficulties in identifying nurse consultants' roles $^{(26)}$. Perhaps because of this, both specialists and nurses reported doubts; thus, to improve understanding, it was added an explanation to the word "consulting" in the final version of the Brazilian version of APNCAI.

Regarding Professional Autonomy item 3.5, the specialists replaced the word "privileges" with "norms" because they believe that "institutional regulations" have a more positive connotation in the Brazilian culture.

In the Relationship and Mentoring dimension, the items emphasize the importance of the advanced practice nurse's role as a mediator of the health team and collaborator in constructing individual and collective care plans. The Quality Management, Care Management, and Professional Teaching and Education dimensions underwent very few changes and address topics related to management and teaching, processes that are very present in nurse's work ${ }^{(27)}$.

Although the items deal directly with patient care in the eighth and last dimension, Health Promotion, the specialists did not reach a consensus. To solve this deadlock, the author of the original instrument was called and clarified that APN covers children and older people.

The nurses who participated in the pre-test provided valuable contributions, corroborating the researchers, who state that the 
inclusion and contribution of the target audience were essential to improve the understanding of the instrument, enable greater adherence to its use in clinical practice, ensure the veracity and quality of the collected information ${ }^{(22)}$.

Although the instrument is long, the average time of completion was relatively short, which will help professionals involved in future research not to spend too much time during participation, thus facilitating the applicability.

The partnership of the author of the original instrument throughout the process was fundamental and contributed to the Brazilian version of the APNCAI being made available to the scientific community, managers, and nurses to boost APN implementation in the Brazilian territory.

\section{Study limitations}

As a limitation of this study, we mention that the instrument had only its content validity analyzed, and researchers recommend the measurement, at the end of the cross-cultural adaptation process, of the instruments' measuring properties, which includes other validity tests and reliability tests.

\section{Contribution to the field of Nursing}

The Brazilian version of APNCAI aims to map the competencies of advanced practice nurses and is the first instrument to be made available for the Brazilian culture that can be used both in Primary Health Care and in the hospital setting. Therefore, it is expected to be a valuable tool to promote the implementation of strategies that will contribute to the dissemination and formalization of APN throughout the national territory.

\section{CONCLUSION}

The APNCAI's cross-cultural adaptation process was conducted according to the steps described in the international literature. The content validation of the Brazilian version shows that the instrument can be used in future research. Before implementing an instrument in practice, researchers indicate that a rigorous evaluation process of the measurement properties must be carried out since this allows researchers to obtain valid and reliable results to guide the implementation of interventions. Therefore, due to the lack of validated instruments, in the Brazilian culture that evaluate the competencies of advanced practice nurses, it is strongly recommended to assess the measurement properties of the adapted version of the APNCAI.

\section{ADDITIONAL MATERIAL}

Database available at https://doi.org/10.25824/redu/I8BN5Z

\section{FUNDING AND ACKNOWLEDGEMENT}

The author would like to thank the Coordination for the Improvement of Higher Education Personnel [Coordenação de Aperfeiçoamento de Pessoal de Nível Superior (CAPES)] for the financial support.

\section{REFERENCES}

1. Miranda Neto MV, Rewa T, Leonello VM, Oliveira MAC. Advanced practice nursing: a possibility for primary health care? Rev Bras Enferm. 2018;71(Suppl 1):716-21. https://doi.org/10.1590/0034-7167-2017-067

2. International Council of Nurses. Guidelines on advanced practice nursing [Internet]. Helsinki: ICN; 2020 [cited 2020 Jul 20]. Available from: https://www.icn.ch/system/files/documents/2020-04/ICN_APN\%20Report_EN_WEB.pdf

3. Organização Pan-Americana da Saúde. Ampliação do papel dos enfermeiros na atenção primária à saúde[Internet]. Washington, D.C.: OPAS; 2018[cited 2019 Nov 12]. Available from: https://iris.paho.org/handle/10665.2/34960

4. Bryant-Lukosius D, Valaitis R, Martin-Misener R, Donald F, Peña L, Brousseau L. Advanced practice nursing: a strategy for achieving universal health coverage and universal access to health. Rev Latino-Am Enfermagem. 2017;25:e2826. https://doi.org/10.1590/1518-8345.1677.2826

5. Schneider F, Kempfer SS, Backes VMS. Training of advanced practice nurses in oncology for the best care: a systematic review. Rev Esc Enferm USP. 2021;55:e03700. https://doi.org/10.1590/S1980-220X2019043403700

6. Andriola IC, Sonenberg A e Lira ALBC. Understanding advanced practice nursing as a step towards its implementation in Brazil. Rev Panam Salud Publica. 2020;44:e115. https://doi.org/10.26633/RPSP.2020.11

7. Cassiani SHB, Aguirre-Boza F, Hoyos MC, Barreto MFC, Peña LM, Mackay MCC et al. Competencies for training advanced practice nurses in primary health care. Acta Paul Enferm. 2018;31(6):572-84. https://doi.org/10.1590/1982-0194201800080

8. Conselho Federal de Enfermagem (COFEN). Enfermagem pactua implementação de Práticas Avançadas no Brasil [Internet]. Brasília (DF): 2016. [cited 2019 Nov 12]. Available from: http://www.cofen.gov.br/enfermagem-pactua-implementacao-de-praticas-avancadas-nobrasil_40163.html

9. Toso BRG, Padilha MI, Breda KL. The euphemism of good practice or advanced nursing practice. Esc Anna Nery. 2019;23(3):e20180385. https://doi.org/10.1590/2177-9465-EAN-2018-0385

10. Oliveira JLC, Toso BRGO, Matsuda LM. Advanced practices for care management: reflections on the Brazilian Nursing. Rev Bras Enferm. 2018;71(4):2060-5. https://doi.org/10.1590/0034-7167-2017-0115

11. Bezerril MS, Chiavone FB, Mariz CM, Sonenberg A, Enders BC, Santos VE. Advanced practice nursing in Latin America and the Caribbean: context analysis. Acta Paul Enferm. 2018;31(6):636-43. https://doi.org/10.1590/1982-0194201800087 
12. Sevilla-Guerra S, Zabalegui A. Analysis instruments for the performance of Advanced Practice Nursing. Enferm Clin. 2017;29(2):90-8. https:// doi.org/10.1016/j.enfcli.2017.10.002

13. Honig J, Lindrud SD, Dohrn J. Moving towards universal health coverage: advanced practice nurse competencies. Rev Latino-Am Enfermagem. 2019;27:e3132. https://doi.org/10.1590/1518-8345.2901.3132

14. Sastre-Fullana SP, Morales-Asencio JM, Sesé-Abad A, Bennasar-Veny M, Fernández-Domínguez JC, Pedro-Gómez J. Advanced Practice Nursing Competency Assessment Instrument (APNCAI): clinimetric validation. BMJ Open. 2017;7(2):e013659. https://doi.org/10.1136/ bmjopen-2016-013659

15. Beaton DE, Bombardier C, Guillemin F, Ferraz MB. Recommendations for the cross- cultural adaptation of the DASH \& QuickDASH outcome measures [Internet]. Institute for Work \& Health: Canada; 2007 [cited 2021 May 20]. Available from: http://www.dash.iwh.on.ca/system/ files/X-CulturalAdaptation-2007.pdf

16. Gagnier JJ, Lai J, Mokkink LB, Terwee CB. COSMIN reporting guideline for studies on measurement properties of patient-reported outcome measures. Qual Life Res. 2021;30(8):2197-2218. https://doi.org/10.1007/s11136-021-02822-4

17. Alexandre NMC, Coluci MZO. Content validity in the development and adaptation processes of measurement instruments. Cien Saude Colet 2011;16(7):3061-7. https://doi.org/10.1590/S1413-81232011000800006

18. Pasquali L. Princípios de elaboração de escalas psicológicas. Rev Psiquiatr Clín [Internet]. 1998 [cited 2019 Nov 12];25(5):206-13. Available from: http://ppget.ifam.edu.br/wp-content/uploads/2017/12/Principios-de-elaboracao-de-escalas-psicologicas.pdf

19. Terwee CB, Prinsen CAC, Chiarotto A, Westerman MJ, Patrick DL, Alonso J, et al. COSMIN methodology for evaluating the content validity of patient-reported outcome measures: a Delphi study. Qual Life Res. 2018;27(5):1159-70. https://doi.org/10.1007/s11136- 018-1829-0

20. Fleiss JL, Levin B, Paik MC. J. Statistical methods for rates and proportion: New York: John Wiley; 2003. 800p.

21. Góes FGB, Ledo BC, Santos AST, Pereira-Ávila FMV, Silva ACSS, Christoffel MM. Cultural adaptation of Infant Feeding Intentions Scale (IFI) for pregnant women in Brazil. Rev Bras Enferm. 2020;73(Suppl 4):e20190103. https://doi.org/10.1590/0034-7167-2019-0103

22. Costa TF, Pimenta CJ, Silva CR, Bezerra TA, Viana LR, Ferreira GR, et al. Cross-cultural adaptation of the Bakas Caregiving Outcome Scale to Brazilian Portuguese. Acta Paul Enferm. 2021;34:eAPE01861. https://doi.org/10.37689/acta-ape/2021AO01861

23. Epstein J, Osborne RH, Elsworth GR, Beaton DE, Guillemin F. Cross-cultural adaptation of the Health Education Impact Questionnaire: experimental study showed expert committee, not back-translation, added value. J Clin Epidemiol. 2015;68(4):360-9. https://doi. org/10.1016/j.jclinepi.2013.07.013

24. Carnut L. Care, integrality and primary care: essential articulation to reflect on the health sector in Brazil. Saude Debate. 2017;41(115):117786. https://doi.org/10.1590/0103-1104201711515

25. Ebell MH, Sokol R, Lee A, Simons C, Early J. How good is the evidence to support primary care practice? Evid Based Med. 2017;22(3):88-92. https://doi.org/10.1136/ebmed-2017-110704

26. Giles M, Parker V, Mitchell, R, Conway J. How do nurse consultant job characteristics impact on job satisfaction? An Australian quantitative study. BMC Nurs. 2017:16(51):2-10. https://doi.org/10.1186/s12912-017-0246-y

27. Sanna MC. Os processos de trabalho em enfermagem. Rev Bras Enferm. 2007;60(2):221-4. https://doi.org/10.1590/ S0034-71672007000200018 